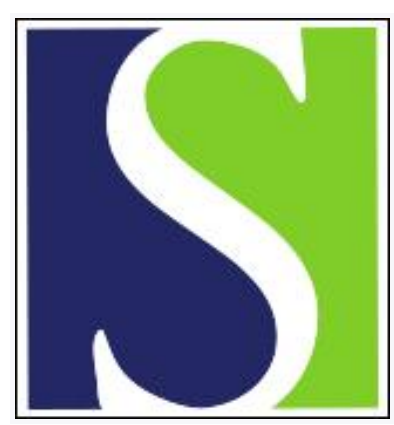

Scand J Work Environ Health 1993;19(3):168-174

https://doi.org/10.5271/sjweh.1485

Issue date: 01 Jun 1993

Morbidity among unemployed and work-incapacitated men in The Netherlands.

by van der Horst F, Muris JW, Nijhuis FJ

Affiliation: Department of General Practice, University of Limburg, Maastricht, The Netherlands.

This article in PubMed: www.ncbi.nlm.nih.gov/pubmed/8367694

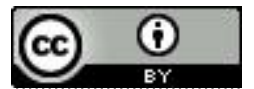




\title{
Morbidity among unemployed and work-incapacitated men in The Netherlands
}

\author{
by Frans GEM van der Horst, PhD, ${ }^{1}$ Jean WM Muris, MD, ${ }^{1}$ Frans JN Nijhuis, $\mathrm{PhD}^{2}$
}

\begin{abstract}
van der HORST FGEM, MURIS JWM, NIJHUIS FJN. Morbidity among unemployed and work-incapacitated men in The Netherlands. Scand J Work Environ Health 1993;19:168-74. As yet, the relationship between unemployment and physical health has not sufficiently been clarified. With a longitudinal approach a representative Dutch panel study and a study on a health center population were carried out. They involved work-incapacitated and unemployed men between 21 and 65 years of age. Men incapacitated for work were in poorer health than matched working men; the same was true in a three-year follow-up. Unemployed and working men were shown to be equally healthy. The physical health of the incapacitated men decreased with time but that of the unemployed men did not. This finding implies that unemployment per se does not lead to poorer health. Differences in social security systems seem to interfere with an international comparison of the consequences of unemployment on health. International research should distinguish more explicitly between those who are unemployed for economic reasons or incapacitated for work for medical reasons.
\end{abstract}

Key terms: incapacity, morbidity, unemployment.

Although the findings regarding the effects of unemployment on nonphysical health aspects are relatively clear, the effects of unemployment on physical health are not clear at all $(1-7)$. Several authors have shown that it must be kept in mind that poor health might play an initial role in becoming unemployed. It has even been suggested that the increased mortality of unemployed men simply reflects their health status before unemployment $(8-10)$. Therefore, the possibility should be considered that different and contradictory findings may reflect differences in social security systems between countries. As a consequence unhealthy jobless people receive the label unemployed in one country and work-incapacitated in another.

Thus far, Brenner's (11) macroeconomic findings that unemployment would lead to poorer health and even death in some countries but not in others have been heavily criticized by other researchers who did secondary analyses on the same research data. The latter have pointed out that the differences can be explained by variations in social, cultural, and economic settings. Pitfalls in macroresearch have been widely discussed (12-16).

As stated, a disturbing factor in the relation between morbidity and unemployment can be found in differences between social security systems. In other words some people without a job may be defined

1 Department of General Practice, University of Limburg, Maastricht, The Netherlands.

2 Department of Medical Psychology, University of Limburg, Maastricht, The Netherlands.

Reprint requests to: Dr JWM Muris, Dept of General Practice, University of Limburg, PO Box 616, 6200 MD Maastricht, The Netherlands. as work incapacitated in The Netherlands, whereas the same people might be defined as unemployed in Belgium as a result of differences in the social security systems of the two countries. The importance of this possibility becomes clear when one realizes that the number of persons granted invalidity pensions per 1000 inhabitants in The Netherlands is three times as high as in Belgium and twice as high as in what once was West Germany (17).

The Netherlands has two relevant social security laws in relation to unemployment and health: the Unemployment Insurance Act and the Incapacity Insurance Act. These two acts result in two separate groups of jobless people. First there are those who, due to illness or disability, have been jobless for more than a year. They receive a pension under the Incapacity Insurance Act, which provides more income security over a longer period of time than does an unemployment benefit. This category of disabled individuals is large in The Netherlands as compared with other countries. Second, there are unemployed people looking for a job.

Many who are considered incapacitated in The Netherlands are considered unemployed in other countries. In these other countries this lack of delineation might lead to higher morbidity among the unemployed. In our study we have therefore differentiated between people unemployed for economic reasons and people unemployed for medical reasons (incapacitated).

Another cause of diverging research findings might be the cross-sectional nature of many previous studies. We therefore decided to set up a longitudinal survey. The question under study then was: Is unemployment a cause of poorer physical health among men? 


\section{Subjects and methods}

The following two sources of information were used: (i) a (national) panel study based on data gathered from a nationwide panel during 1981-1983 and (ii) a study based on data gathered from general practitioners during 1987-1990.

\section{Panel study}

The panel study consisted of a representative sample of nonworking and working men and women who were between the ages of 21 and 65 years and were interviewed in 1981 and 1983. Their cooperation was not sought as part of a study on the relation between health and unemployment, but in the context of a health survey, which was the original purpose of the study $(3,18,19)$.

Moreover, only the last part of the interview dealt with work status. It has been suggested that people who are not employed tend to give biased answers to health questions. The direction of this bias would depend on the cause of unemployment. Those who have lost work due to economic reasons - the unemployed - may pretend better health in order to show their willingness to work. Those who have lost work because of poor health - the incapacitated for work - may pretend worse health in order to justify their status of being incapacitated (20). As a result, some of those who are incapacitated for work are suspected of having a health condition with which they are actually able to work. They are the so-called "hidden" unemployed among the work-incapacitated. In 1986 the Dutch government estimated the size of this group to be approximately $50 \%(21,22)$. With this set-up an attempt was made to prevent potential bias in the answering of health questions. The panel included both employed and jobless respondents. The latter category consisted of some unemployed persons and some people incapacitated for work. It was decided not to include women in our study, mainly because the numbers of unemployed and work-incapacitated women were too small.

The questions repeated in 1981 and 1983 enabled us to carry out a cross-sectional and longitudinal study on the relation between work status and health changes. The cross-sectional comparisons were analyzed with the use of an analysis of variance. As for the longitudinal study, matched pairs were made of unemployed and work-incapacitated men on one hand and employed men on the other, with regard to age, marital status, socioeconomic status (education and last profession), district, and degree of urbanization. In the longitudinal study differences between matched groups in 1981 and 1983 were tested with the Mann-Whitney U and the Wilcoxon rank score $\mathrm{W}$ tests. The differences for the matched groups between 1981 and 1983 were based on Wilcoxon's matched pairs test.

Self-reported health was determined from the number of chronic diseases, number of consultations, physical complaints, health assessment, and selfmedication.

During the follow-up 28 men dropped out, and 12 others found work again (table 1). As for the incapacitated and unemployed men, the number of dropouts for health reasons (death and sickness) was significantly higher among the incapacitated men $(\mathrm{P}<0.05)$.

\section{General practitioner study}

The possibility of including a physician's opinion on their patients' health status was seen as a valid reason for carrying out our study among the patient population of general practitioners.

The patients of our primary health center at the time of the study numbered about $10000-60 \%$ of whom were insured in the state-controlled social health insurance scheme. In March 1987 all of the men between 21 and 64 years of age were sent a questionnaire with an accompanying letter from their general practitioner and the head of the Department of General Practice of the University of Limburg.

The questions referred to background variables such as age, gender, marital status, and insurance. In addition, data on family structure, socioeconomic status (last profession), and previous education were collected. The work situation was explored in terms of training, military obligations, unemployment, inability to work, early retirement, and pensioning. From their patient files the general practitioners extracted a "problem list" of these men.

In March 1990 a follow-up study took place which was intended to reveal which patients from the cohort had died in the preceding three years. In order to establish whether men belonging to the cohort had died between 1987 and 1990, we consulted the files of deceased patients. If patients had left the practice (eg, because they had moved away), their new general practitioners were consulted.

In the general practitioner study, health status was determined in terms of diagnoses and chronic complaints, as derived from the medical records (23). The procedure for collecting the diagnoses was supported by the Registration Network of the University of Limburg (24). Diagnoses were categorized accord-

Table 1. Reasons for the work-incapacitated $(N=179)$ and unemployed $(N=49)$ men dropping out after the first survey in
1981 .

\begin{tabular}{lcc}
\hline Reasons & $\begin{array}{c}\text { Incapacitated } \\
\text { men } \\
(\mathbf{N})\end{array}$ & $\begin{array}{c}\text { Unemployed } \\
\text { men } \\
(\mathrm{N})\end{array}$ \\
\hline Found work again & 11 & 12 \\
Severe morbidity & 9 & - \\
Death & 15 & 1 \\
Other (reluctance, moved, & 47 & 15 \\
not at home) & 82 & 28 \\
\hline Total dropout & & \\
\hline
\end{tabular}


ing to the International Classification of Primary Care (ICPC) (25) and were fed directly into the health center computer. The ICPC can be divided into categories referring to organ systems. With this instrument the general practitioner can also record psychological and social health.

Diagnoses were attributed active status if, in the general practitioner's opinion, they presented a threat to the subject's health or caused so much distress in the patient's daily life that they required the attention of the general practitioner. This criterion applied, for instance, to special diets, medication or specific therapies, ongoing investigations, a progressive course of complaints or diseases, and regular monitoring by physicians.

For a comparison of the unemployed and incapacitated men, matched pairs were made for the variables age, marital status, socioeconomic status, type of insurance, and practitioner.

\section{Results}

\section{Response}

The response rate for the total panel was $73 \%$ in 1981 $(\mathrm{N}=1278)$ and $70 \%$ in $1983(\mathrm{~N}=1193)$. Of the 1981 population, $69 \%$ also took part in the 1983 study. The new respondents in 1983 were approached to fill the gap in the study population. Table 2 presents the number of unemployed, work-incapacitated, and

Table 2. Number of unemployed, work-incapacitated, and employed men in a Dutch panel study for the years 1981, 1983, and $1981-1983$. $^{\mathrm{a}}$

\begin{tabular}{lccc}
\hline Year & $\begin{array}{c}\text { Un- } \\
\text { employed } \\
\text { men } \\
(\mathrm{N})\end{array}$ & $\begin{array}{c}\text { Incapaci- } \\
\text { tated } \\
\text { men } \\
(\mathrm{N})\end{array}$ & $\begin{array}{c}\text { Employed } \\
\text { men } \\
(\mathrm{N})\end{array}$ \\
\hline 1981 & 49 & 179 & 381 \\
1983 & 89 & 155 & 413 \\
$1981-1983$ (inter- & & & \\
viewed twice) & 21 & 97 & 274 \\
$1981-1983$ (matched) & 17 & 55 & 72 \\
\hline
\end{tabular}

a Work status was based on information received in 1981 and 1983 , excluding those who had died or were found to be severely ill in 1983.

Table 3. Unemployed, work-incapacitated, and employed men among the patients of a Dutch health center. ${ }^{a}$

\begin{tabular}{lcccc}
\hline & $\begin{array}{c}\text { Un- } \\
\text { employed } \\
\text { men } \\
(\mathrm{N})\end{array}$ & $\begin{array}{c}\text { Incapaci- } \\
\text { tated } \\
\text { men } \\
(\mathrm{N})\end{array}$ & $\begin{array}{c}\text { Employed } \\
\text { men } \\
(\mathrm{N})\end{array}$ & Total \\
\cline { 2 - 5 } & 63 & 170 & 923 & $1156^{\mathrm{b}}$ \\
$\begin{array}{l}\text { Population } 1987 \\
\begin{array}{l}1987-1990 \\
\text { matchedc }\end{array}\end{array}$ & 43 & 90 & 133 & 266 \\
\hline
\end{tabular}

a Work status was based on the situation in 1987, including those who died between 1987 and 1990.

b Excluding early retirement $(N=41)$, part-time jobs $(N=79)$, students $(\mathrm{N}=38)$, others or missing $(\mathrm{N}=88)$

c Matched pairs on the basis of age, marital status, socioeconomic status, type of insurance, and practitioner. Percentage matched: unemployed men $68 \%$, incapacitated men $53 \%$, employed men $14 \%$. employed men who were interviewed in 1981 and 1983. It also shows the number of those interviewed twice and the number of unemployed and work-incapacitated men who were matched with workers. When comparing those who were matched with those who could not be matched, we found no differences in the health parameters and demographic variables.

Of those who were unemployed in $1983,25 \%$ had been without work for more than two years, and 75\% of those who were incapacitated for work in 1983 had been without work for more than two years.

Of the men who were without work in 1981, 23 had found work in 1983, 12 of whom had been unemployed in 1981 and 11 of whom had been incapacitated for work.

The population of the health center was about 10000 patients. There were 2158 men between the ages of 21 and 65 years. The response rate was $65 \%$. Table 3 shows the number of unemployed, work-incapacitated and employed men, excluding students and those who were partly incapacitated, had parttime jobs, had early retired, and the like. Those who were matched successfully did not differ from those who were not matched on the demographic and health variables involved.

\section{Cross-sectional comparisons of morbidity}

In the panel study the unemployed subjects and the workers did not differ in health in 1981 and 1983.

Table 4. Comparison between the work-incapacitated and unemployed men and their matched groups of employed men with respect to their diagnoses.

\begin{tabular}{lcccc}
\hline & \multicolumn{5}{c}{ Number of problems } \\
\cline { 2 - 5 } & Mean & SD & Range & Median \\
\cline { 2 - 5 } & & & & \\
Incapacitated men & 3.2 & 1.8 & $0-8$ & $2.5^{* * *}$ \\
$(\mathrm{~N}=90)$ & 1.8 & 1.4 & $0-6$ & 1.2 \\
Employed mena $(\mathrm{N}=90)$ & 2.0 & 1.6 & $0-7$ & 0.98 \\
Unemployed men $(\mathrm{N}=43)$ & 1.5 & 1.5 & $0-7$ & 0.74 \\
Employed men' $(\mathrm{N}=\mathbf{4 3})$ & & &
\end{tabular}

a Matched with the incapacitated men.

b Matched with the unemployed men.

$* * P<0.001$.

Table 5. Distribution of health problems among the matched incapacitated $(\mathrm{N}=90)$ and employed $(\mathrm{N}=90)$ men according to seven diagnostic categories of the International Classification of Primary Care (ICPC).

\begin{tabular}{|c|c|c|}
\hline \multirow[b]{2}{*}{ ICPC category } & \multicolumn{2}{|c|}{ Number of health problems } \\
\hline & $\begin{array}{l}\text { Incapacitated } \\
\text { men }\end{array}$ & $\begin{array}{c}\text { Employed } \\
\text { men }\end{array}$ \\
\hline $\begin{array}{l}\text { Digestive } \\
\text { Circulatory } \\
\text { Locomotor } \\
\text { Psychological } \\
\text { Respiratory } \\
\text { Metabolic or endocrine } \\
\text { Social }\end{array}$ & $\begin{array}{l}27^{\star \star} \\
35^{\star \star} \\
33 \\
38^{\star \star} \\
19^{\star \star} \\
14^{\star \star} \\
15^{*}\end{array}$ & $\begin{array}{r}19 \\
17 \\
26 \\
12 \\
14 \\
5 \\
8\end{array}$ \\
\hline Total & 181 & 101 \\
\hline
\end{tabular}


Table 6. Comparison between the matched unemployed and employed men with respect to reported health $(\mathrm{N}=17$ pairs).

\begin{tabular}{|c|c|c|c|c|c|}
\hline & $\begin{array}{c}\text { Chronic } \\
\text { diseases } \\
(\%)^{\mathrm{a}}\end{array}$ & $\begin{array}{l}\text { Visits to a } \\
\text { physician } \\
\text { (mean) }\end{array}$ & $\begin{array}{l}\text { Physical } \\
\text { complaints } \\
\text { (mean) }\end{array}$ & $\begin{array}{l}\text { Health } \\
\text { assessment } \\
\text { (mean) }\end{array}$ & $\begin{array}{c}\text { Self- } \\
\text { medication } \\
(\%)^{\mathrm{a}}\end{array}$ \\
\hline \multicolumn{6}{|c|}{ Unemployed men } \\
\hline $\begin{array}{l}\text { In } 1981 \\
\text { In } 1983\end{array}$ & $\begin{array}{l}18 \\
18\end{array}$ & $\begin{array}{l}2.5^{\mathrm{c}} \\
1.1^{\mathrm{d}}\end{array}$ & $\begin{array}{l}3.9 \\
3.3\end{array}$ & $\begin{array}{l}3.9 \\
3.9\end{array}$ & $\begin{array}{l}59^{c} \\
23^{d}\end{array}$ \\
\hline \multicolumn{6}{|c|}{ Employed men } \\
\hline $\begin{array}{l}\text { In } 1981 \\
\text { In } 1983\end{array}$ & $\begin{array}{l}20 \\
27\end{array}$ & $\begin{array}{l}1.9^{c} \\
4.1\end{array}$ & $\begin{array}{l}6.1 \\
5.4\end{array}$ & $\begin{array}{l}3.9 \\
3.9\end{array}$ & $\begin{array}{l}53 \\
53\end{array}$ \\
\hline
\end{tabular}

a Percentage of group.

$1=$ very poor, $2=$ poor, $3=$ moderate, $4=$ good, $5=$ very good.

c $\mathrm{P}<0.05,1981$ versus 1983 for the same group of workers.

d $\mathrm{P}<0.05$, unemployed workers versus employed workers in same year.

Table 7. Comparison between the matched work-incapacitated and employed men with respect to their health ( $N=55$ pairs).

\begin{tabular}{|c|c|c|c|c|c|}
\hline & $\begin{array}{c}\text { Chronic } \\
\text { diseases } \\
(\%)^{a}\end{array}$ & $\begin{array}{c}\text { Visits to a } \\
\text { physician } \\
\text { (mean) }\end{array}$ & $\begin{array}{l}\text { Physical } \\
\text { complaints } \\
\text { (mean) }\end{array}$ & $\begin{array}{c}\text { Health } \\
\text { assessment } \\
\text { (mean) }^{\text {b }}\end{array}$ & $\begin{array}{c}\text { Self- } \\
\text { medication } \\
(\%)^{a}\end{array}$ \\
\hline \multicolumn{6}{|c|}{ Incapacitated workers } \\
\hline $\begin{array}{l}\text { In } 1981 \\
\text { In } 1983\end{array}$ & $\begin{array}{l}76^{c} \\
69^{c}\end{array}$ & $\begin{array}{l}5.8^{c} \\
5.7^{c}\end{array}$ & $\begin{array}{l}8.5^{c, d} \\
7.4^{c}\end{array}$ & $\begin{array}{l}3.2^{c} \\
3.3^{c}\end{array}$ & $\begin{array}{l}51^{c} \\
53^{c}\end{array}$ \\
\hline \multicolumn{6}{|c|}{ Employed workers } \\
\hline $\begin{array}{l}\text { In } 1981 \\
\text { In } 1983\end{array}$ & $\begin{array}{l}20 \\
20\end{array}$ & $\begin{array}{l}1.9 \\
2.1\end{array}$ & $\begin{array}{l}3.6 \\
3.1\end{array}$ & $\begin{array}{l}4.0 \\
4.1\end{array}$ & $\begin{array}{l}33 \\
43\end{array}$ \\
\hline
\end{tabular}

a Percentage of group.

b $1=$ very poor, $2=$ poor, $3=$ moderate, $4=$ good, $5=$ very good.

c $P<0.001$, incapacitated workers versus employed workers in same year.

d $P<0.001,1981$ versus 1983 for the same group of workers.

The incapacitated men had poorer health than workers in 1981 and $1983(\mathrm{P}<0.01)$ on all of the health parameters when demographic variables were controlled for. In the general practitioner study the number of ICPC diagnoses was compared for the matched incapacitated and unemployed subjects and workers (table 4). The incapacitated men had more diagnoses than the workers, and the unemployed men did not differ from the workers in their number of diagnoses. Furthermore unemployed and incapacitated men, matched with employed men, were compared according to the ICPC categories (table 5). Whereas the unemployed men did not differ from the workers, the incapacitated men did differ from the workers with respect to circulatory, psychological, and metabolic/endocrine problems.

\section{A longitudinal approach}

In the panel population the health status of those who were interviewed twice and who had the same work status in 1981 and 1983 were compared. The results for the unemployed and incapacitated men are presented separately in tables 6 and 7 . The unemployed and employed men did not differ in either 1981 or 1983. The unemployed men tended to have better health than the employed men in 1983 in that they had made fewer visits to their doctor and had a smaller percentage using self-medication (table 6).

The incapacitated men were in considerably poorer health than the employed men in both 1981 and 1983 (table 7). The main conclusion was that being out of work for a longer period of time due to incapacitation does not lead to poorer health. There is a tendency towards fewer physical complaints, although the number of complaints among the incapacitated men remained considerably higher than among the employed men.

To rule out any chance effects, we used the results of the general practitioner study over three years (1987-1990) in a mortality study. The results are presented in table 8 , which includes a reference group of employed men. Table 8 shows that the number of incapacitated men who died between 1987 and 1990 was higher than the number of deceased workers with whom they were matched. There was no difference between the unemployed subjects and their working counterparts.

\section{Discussion}

Our research design was intended to facilitate a comparison between unemployed or work-incapacitated 
Table 8. Causes of death during three years of follow-up of work-incapacitated and unemployed men with their matched groups of employed men.

\begin{tabular}{|c|c|}
\hline & Causes of death \\
\hline $\begin{array}{l}\text { Incapacitated } \\
\text { men }(N=90)\end{array}$ & $\begin{array}{l}\text { Myocardial insufficiency }(N=3) \text {; carci- } \\
\text { noma of the thyroid with metastases } \\
(N=1) \text {; carcinoma of the stomach, died } \\
\text { during operation }(N=1) \text {, complication } \\
\text { of stomach operation }(N=1) \text {; unknown } \\
\text { cause }(N=1)\end{array}$ \\
\hline $\begin{array}{l}\text { Employed mena } \\
(\mathrm{N}=90)\end{array}$ & $\begin{array}{l}\text { Carcinoma of the right lung with bone } \\
\text { metastases }(N=1) \text {; acute myocardial in- } \\
\text { farction }(N=1)\end{array}$ \\
\hline $\begin{array}{l}\text { Unemployed men } \\
(N=43) \\
\text { Employed men } \\
(N=43)\end{array}$ & $\begin{array}{l}\text { Carcinoma of the stomach }(\mathrm{N}=1) \\
\text { No deaths }\end{array}$ \\
\hline
\end{tabular}

a Matched with the incapacitated men.

b Matched with the unemployed men.

men and employed men in cross-sectional and longitudinal analyses. The study was limited to men only, one of the reasons being that unemployed and incapacitated people in The Netherlands are predominantly men. An explanation may be the Dutch tradition that women do not usually have paid work ( $70 \%$ of all women between 15 and 65 years of age). Another, directly associated, reason is that the number of unemployed and work-incapacitated women in the representative panel study was too small.

In our investigation one source of material was a representative nationwide panel study on health (1981-1983) and the other was a panel of all male patients in a health center (1987-1990). In both studies, the ages of the subjects ranged between 21 and 65 years. The general practitioner study had one limitation, namely, it was not possible to determine the work status of all of the male patients in 1990 . Therefore our investigation had the characteristics of triangulation (26): a representative national sample, a sample of patients of general practitioners (both of them panel studies), and a validity study (based on a comparison between self-reported health and health status as assessed by family physicians). Both the national surveys of 1981 and 1983 and the general practitioner study of 1987 showed that (i) the unemployed and employed men did not differ in physical health, (ii) the work-incapacitated men were in poorer health than the employed men, (iii) long-term unemployment led to a smaller number of general practitioner consultations and less self-medication. The similarity between the results of the surveys and the general practitioner study also proved the validity of self-reported health.

When the unemployed and incapacitated men were followed in a longitudinal study over a period of two years, physical health scarcely appeared to change. What little change there was tended towards improved rather than poorer health. Nevertheless, the incapacitated subjects were always in poorer health than their matched workers, whereas the unemployed subjects hardly differed from the workers. The question arises of whether there might have been a selection effect. If "dropouts" due to severe illness and particularly death are included in our national panel, the following conclusion emerges: there remains no difference in health between unemployed and employed men, while incapacitated men differ considerably from employed men.

If the death cases in the general practitioner study over three years are included, the number of incapacitated men who died in that period was much higher than the number who died in a matched group of workers. The unemployed men did not differ from the matched workers in this respect. In other words the different samples from the same populations resulted in similar patterns. Therefore, it is our overall conclusion that incapacitated men not only have poorer initial health than workers, but that their health status also deteriorates with time. This is not the case with unemployed men, and therefore it can be concluded that physical health does not deteriorate as a result of being out of work, but as a result of an autonomous process directly related to disease.

Still, the question remains of whether health status is a contributing factor in finding a new job if one is incapacitated for work. This matter was explored within the national panel study. The unemployed men proved to have better chances to find work again than the incapacitated men (24 versus $6 \%$ ). The unemployed and incapacitated subjects who had succeeded in finding work again since 1981 had better health on some of our parameters than those who remained without work. These results demonstrate that finding work has an additional positive health effect, and this result is in accordance with the findings by Verkley (27).

Our results thus far seem to contradict the findings of Verkley \& Spruit (28), who stated that unemployment leads to deteriorating physical health. We believe that their conclusions are dubious because of their operationalization of health. But we can agree with their conclusion that, given their research design and their health indicators, unemployment leads to a deterioration of mental health. A comparable, national investigation of the differences between unemployed and employed subjects regarding their use of medication, general practitioner visits, and days spent in bed for reasons of illness did not reveal any differences (29).

Our findings do not mean that unemployment may never lead to a deterioration of physical health. Indeed, deterioration may occur, in The Netherlands and abroad, as soon as changes in the safety net of the social security system (in The Netherlands, the Unemployment Insurance Act) leads to a further income reduction. If that is the case, it is poverty as a consequence of unemployment rather than unemployment which would lead to poor health. 
Differences in social security systems might constitute an explanation for seemingly contradictory findings among unemployed men. One of the effects of the Dutch social security system, as compared with those of other countries, is that a distinction is made between unemployed people with an illness or disability and unemployed people without an illness or disability. It should be kept in mind, however, that health selection criteria are often applied to employees with low job security. If the job market collapses, employees who have lower capacities for work or are economically less remunerative (ie, have defective health) will be the first to become redundant. In the literature this phenomenon is known as the healthy worker effect. Incapacitated workers in The Netherlands have always received their disability pensions at an earlier stage than those in other Western European countries (17). The Incapacity Insurance Act provides employers with the opportunity to rid themselves of workers with some illness or inability without being "socially irresponsible." The choice of disability pensions as study end points of unemployment [eg, Westin et al (30)] is questionable, on the condition that those who are unemployed for a long time are more likely to be granted a disability pension when they have an illness or disability than those in the reference population who are unemployed and who have an illness or disability as well.

In our neighboring countries, unhealthy employees run higher risks of ending up receiving unemployment benefits than in The Netherlands because both employers' and employees' interests in our country encourage a strong tendency towards disability pensions. In other words, those who are in poor health and consequently are at risk of becoming unemployed may use other methods to obtain insurance benefits. Thus we can speak not only of a healthy worker effect, but also of a healthy unemployed effect.

There is a relatively large proportion of healthy people in both the unemployed and employed population. It is therefore not surprising that about $27 \%$ of both employed and unemployed men have chronic health complaints, whereas this figure is $83 \%$ for those who are incapacitated (3). In other words the number of "hidden unemployed" among the workincapacitated is much lower than the government's estimate of $50 \%$ (21).

From our observations, it is not possible to make direct extrapolations to health effects on long-term unemployed workers in other countries. Neither can findings from surrounding countries be directly applied to the Dutch situation.

When it comes to determining the physical health effects of unemployment, it is not only important to know the financial situation (poverty problem), but also the assumptions of the health selection criteria for those with long-term unemployment. Therefore, if comparable longitudinal studies are carried out in other European countries, excess mortality is likely to be found among unemployed as compared with employed subjects, and such a finding leads to the conclusion that "unemployment kills" - which would be another contradictory result. If the same studies were restricted to physical disorders, they would lead to the conclusion that "unemployment leads to disease." Thus the social security system may be a crucial pitfall when the health effects of unemployment are being investigated.

This situation calls for international research taking into account differences in social security systems and applying the same health measures in studies of the health effects of unemployment.

\section{Acknowledgments}

Thanks are due to $\mathrm{H}$ van Montfort, $\mathrm{R}$ Schmeitz, and other members of the MEMIC (Medisch En Maatschabbelyk Informatie Centrum) department of the University of Limburg for their invaluable help, especially with the data analysis, and to I van Noppen for typing the text.

\section{References}

1. Nijhuis F, Knipschild P. Werkloosheid, dreigende werkloosheid en gezondheid: een literatuuronderzoek [Unemployment, imminent unemployment, and health: a literature review]. Maastricht: Rijksuniversiteit Limburg, 1982.

2. Warr PB. Werk en werkloosheid [Employment and unemployment]. In: Handboek arbeids- en organisatiepsychologie [Handbook of labour and organizational psychology]. Deventer: Van Loghum Slaterus, 1983;9: $213-31$.

3. FGEM van der Horst. Gezondheid en niet werken [Health and no job] [dissertation]. Maastricht: Rijksuniversiteit Limburg, 1988.

4. Eyer J, Sterling P. Stress related mortality and social organization. Rev Radical Politl Econ 1977;9:1-44.

5. Nijhuis F. Economische achteruitgang in bedrijven en ziekteverzuim [Economic decline in firms and absenteeism]. Mens en Onderneming 1984;5:400-13.

6. Kasle SV, Cobb S. Blood pressure changes in men undergoing job loss. Psychosom Med 1970:32:19-38.

7. Meems A. Een onderzoek naar de effecten van een dreigende bedrijfssluiting (70 recidivi en 70 primi) [A study of the effects of imminent closing down]. Tijdschr Soc Geneeskd 1981;59:565-71.

8. Moser KA, Fox AJ, Jones DR. Unemployment and mortality: the OPCS longitudinal study. In: Wilkinson R. ed. Class and health: research and longitudinal data. London/New York: Tavistock, 1986.

9. Brinkman C. Health problems in the initial phase of unemployment: health policy implications of unemployment. Copenhagen: World Health Organization, 1985.

10. Wood D. The DHSJ cohort study of unemployed men: men registering as unemployed in $1978-$ a longitudinal study DHSJ, 1982. In: Fagin L, Little M, ed. The forsaken families. Harmondsworth: Penguin Books, 1984.

11. Brenner MH. Mortality and the national economy: a review, and the experience of England and Wales. Lancet 1979;2:568-73.

12. Gravelle HSE, Hutchinson G, Stern J. Mortality and unemployment: a critique of Brenner's time series analysis. Lancet 1981;2: 675-79. 
13. Spruit ID. Unemployment, employment and health [dissertation]. Leiden: Rijksuniversiteit Leiden, 1983.

14. McAvinchy ID. Unemployment and mortality: some aspects of the Scottish case 1950-1978. Scott J Polit Econ 1984;31:827-35.

15. Gravelle HSE. Time series analysis of mortality and unemployment [editorial]. J Health Econ 1984;3:297305.

16. van der Horst FGEM, Nijhuis FJN, Muris JWM, Philipsen H, Van der Grinten RF. Causality in the relation between health and long-term unemployment. In: Verhaar CHA, Jansma LG, de Goede MPM, van Ophem JAC, de Vries A, ed. On the mysteries of unemployment. Amsterdam: Kluwer Academic Publishers, 1992:225-52.

17. Prins R. Sickness absence in Belgium, Germany (FR) and The Netherlands: a comparative study [dissertation]. Maastricht: Rijksuniversiteit Limburg, 1990.

18. Adriaanse H, Drop MJ, Halfens R, Philipsen H. Leeft Nederland Oké? Maastricht: Rijksuniversiteit Limburg, 1981.

19. Halfens R, Drop MJ, Philipsen H. Leefwijze en subjectieve gezondheid van een panel uit de Nederlandse bevolking [Life-style and subjective health of a panel from the Dutch population]. Maastricht: Rijksuniversiteit Limburg, 1984.

20. Merens-Riedstra HW. Leven zonder werk: een sociaalwetenschappelijk onderzoek naar arbeidsongeschiktheid [Life without work: a social-scientific study regarding work incapacity] [dissertation]. Maastricht: Rijksuniversiteit Limburg, 1981.

21. Hermans D, Jas C, Schraven B. Schat de regering de arbeidsongeschiktheidsschatting juist in? [Does the government assess the work-incapacitated estimate correctly?]. Sociaal Maandblad Arbeid 1986;February: $127-36$.

22. Aarts CJM, De Jong PR. Economic aspects of disa- bility behavior [dissertation]. Rotterdam: Erasmus Universiteit Rotterdam, 1990.

23. O'Toole B, Driver B, Britt H, Bridges-Webb C. Using general practitioners to measure community morbidity. Int J Epidemiol 1991;20:1125-32.

24. Metsemakers JFM, Höppener P, Knottnerus JA, Kocken RJJ, Limonard CBG. Computerized health information in the Netherlands: a registration network of family practices. Br J Gen Pract 1992;42:102-6.

25. Lamberts $\mathbf{H}$, Wood $\mathrm{M}$, ed. ICPC international classification of primary care. Oxford: Oxford University Press, 1987.

26. Nijhuis FJN. Beoordelingen van organisatiekenmerken [Assessment of organizational characteristics] [dissertation]. Maastricht: University of Limburg, 1984.

27. Verkley H. Langdurige werkloosheid, werkhervatting en gezondheid [Long-term unemployment, re-employment, and health] [dissertation]. Amsterdam: Lisse, 1988.

28. Verkley H, Spruit IP. Werkloosheid en gezondheid: een wederkerige relatie [Unemployment and health: a mutual relationship]. In: Spruit IP, Tazelaar F, ed. Leven met werkloosheid [Living with unemployment]. Groningen: Wolters-Noordhof, 1987:65-83.

29. Becker JW, Vink R. Werklozen, arbeidsongeschikten en werkenden vergeleken [Unemployed, incapacitated, and employed compared]. Den Haag: Sociaal en Cultureel Planbureau, 1984. (Stukwerk 18.)

30. Westin S, Schlesselman JJ, Korper M. Long-term effects of a factory closure: unemployment and disability during ten years' follow-up. J Clin Epidemiol 1989;42:435-41.

Received for publication: 22 July 1992 